\title{
Path Analysis to Control The Multicollinearity among Yield Components In Maize (Zea mays L.)
}

\author{
A.M.S.A. EL-Taweel, M.B.A. EL-Koomy" and W. M. Fares \\ Cent. Lab. For Design \& Stat. Analysis Res.and "Maize \\ Research Sec., Field Crops Research Institute, Agricultural \\ Research Center, Cairo, Egypt.
}

\begin{abstract}
AIELD experiment was carried out at Mallawy Agricultural A Research Station, Elmenia Governorate during 2010 and 2011 seasons to evaluate the performace of sixteen maize hybirds (11 single crosses and 5 three way crosses). Also, to use a modified model of path analysis to control the multicollinearity among yield components when studying the relationship between grain yield and its related characters. The experimental design used was randomized complete block with four replications. As a multiple linear regression model, the independence among the explanatory variables is an important assumption to do the path analysis characterized by validity and goodness of fit. But, this assumption is rarely satisfied because there are strong associations among yield components, which called the multicollinearity problems. Therefore, the present investigation introduced and evaluated a modified path analysis model that could deal and correct the negative effects of multicollinearity problem. Results appeared that the tested descriptive statistics for all studied characters were located at the statistically acceptable range. Highly significant and positive associations were observed between grain yield (ton ha ${ }^{-1}$ ) and each of days to $50 \%$ tasseling, and silking, ear height, number of ears plot $^{-1}$, ear length and number of kernels row ${ }^{-1}$. The Highest values of Variance Inflation Factor (VIF above 10) were recorded for most studied characters ( 7 out of 11 traits) using the coventional path analysis model indicating the presence of multicollinearity. Consequently, the path coefficients were flactuated recording very low values (close to be zero) and other inflated values (above 1) Also, there were some unexpected signs for some path coefficients such as the negative sign of the direct effect for number of kernels row $^{-1}$. The previous negative effects were statistically enough to reject the normal model of path analysis. More accurate results were obtained using the modified model of path analysis because it can overcome the adverse effects of multicollinearity dilemma. The proposed model revealed that the traits of number of ears plot $^{-1}$ and ear length exerted the greatest influence directly or indirectly upon grain yield indicating their importance as selection criteria in improvement of maize breeding programs.
\end{abstract}

Keywords: Maize, Multicollinearity, Path analysis. 
Abbriviations:

DTT = days to tassling, DTS= days to silking, $\mathrm{PH}=$ plant height, $\mathrm{EH}=$ ear height, NEP= number of ears plot ${ }^{-1}, \mathrm{EL}=$ ear length, $\mathrm{ED}=$ ear diameter, $\mathrm{CD}=$ cub diameter, $\mathrm{KD}=$ kernel depth, $\mathrm{NRE}=$ number of rows ear $^{-1}, \mathrm{NKR}=$ number of kernels row ${ }^{-1}$ and $\mathrm{GY}=$ grain yield.

Maize (Zea mays L.) occupied the second place after wheat as a major cereal crop in Egypt. The water required for planting more new arable lands is limited, so it is necessary to increase the yields productivity to meet required cereals for population explosion. Improvement of a complex and low heritable character like grain yield may be more effective using indirect selection through other yield components which show closely positive association with yield and more hertible than yield itself (Wannows et al., (2010). Already, this selection criteria needs complete information about the interrelationships among yield components. Many statistical models are applied to explain the complicated interrelationships among yield components, but choosing the appropriate model is a challenge for breeders and statisticians. Although, simple correlation coefficient is used to quantitfy the direction and size of trait associations, it may not always be effective because it measures the mutual association only between a pair of characters neglecting the complex interrelationships among the other characters (Kang, 1994). The path analysis divides the correlation coefficients into direct and indirect effects of set of traits (yield components) over a response trait (grain yield). The study of causal relationship between yield and its related characters (simple correlation and path analysis) occupied a large area of research in maize (Ivanovic \& Rosic, 1984; Mohamed \& Sedhom, 1993; Arias et al., 1999; Carvalho et al., 2001; Mohammadi et al., 2003; El-Taweel \& Barakat, 2006; Saidaiah et al., 2008; Rafiq et al., 2010 and Wannows et al., 2010). The path coefficient is a partial regression coefficient expressed as a standarized unit. So, like multiple linear regression model, the path analysis could be negatively affected by the multicollinearity problem which occurs when the associations among some independent variables (yield components) are strong. Alternative path analysis model was proposed by Carvalho et al. (1999) to deal and overcome the negative effects of multicollinearity. The proposed model modifies the normal form of path analysis by adding a very small constant value $(\mathrm{k})$ ranged from zero to 1 , to the diagonal elements (unity) of the correlation matrix among yield components. Because the technique is an extension of the ridge regression method proposed by Hoerl \& Kennard (1970, a and b), it is sometimes called Ridge Path Analysis Model. Williams et al. (1979) used ridge regression in soybean while Carvalho et al. (2001) and Bizeti et al. (2004) applied ridge path analysis in maize and soybean, respectively. In Egypt, on maize, no references were found about this methodology. The objective of the present investigation is to use and evaluate an alternative model of path analysis that has the ability to aviod the adverse effects of multicollinearity compared to the original path analysis model.

\section{Materials and Methods}

A field experiment was conducted at Mallawy Experimental Station, Elmenia Governorate during the two successive seasons of 2010 and 2011 to

Egypt. J. Agron. 34, No. 2 (2012) 
evaluate the performance of sixteen maize hybrides, comprising eleven single crosses and five three way crosses. The name and pedigree of the 16 maize crosses used in the study are shown in Table 1.

TABLE 1 . The name and pedigree of 16 maize crosses used in the study.

\begin{tabular}{|l|l|l|}
\hline No. & Name & \multicolumn{1}{|c|}{ Pedigree } \\
\hline 1 & SC 10 & Sids $7 \times$ Sids $63 \quad(\mathrm{~W})$ \\
\hline 2 & SC 122 & Giza $628 \times$ Giza $601(\mathrm{~W})$ \\
\hline 3 & SC 123 & Giza $628 \times$ Giza $602(\mathrm{~W})$ \\
\hline 4 & SC 124 & Giza $629 \times$ Giza $603(\mathrm{~W})$ \\
\hline 5 & SC 128 & Giza $628 \times$ Giza $613(\mathrm{~W})$ \\
\hline 6 & SC 129 & Giza $628 \times$ Giza $612(\mathrm{~W})$ \\
\hline 7 & SC 162 & Giza $639 \times$ Giza $653(\mathrm{Y})$ \\
\hline 8 & SC 164 & Giza $639 \times$ Giza $655(\mathrm{Y})$ \\
\hline 9 & SC 166 & Giza $639 \times$ Giza $656(\mathrm{Y})$ \\
\hline 10 & SC 167 & Giza $639 \times$ Giza $657(\mathrm{Y})$ \\
\hline 11 & SC 168 & Giza $639 \times$ Giza $658(\mathrm{Y})$ \\
\hline 12 & TWC 321 & SC $12 \times$ Sids $7 \quad$ (W) \\
\hline 13 & TWC 310 & SC $10 \times$ Sids $34 \quad$ (W) \\
\hline 14 & TWC 311 & SC $21 \times$ Sids $34 \quad$ (W) \\
\hline 15 & TWC 314 & SC $24 \times$ Sids $34 \quad$ (W) \\
\hline 16 & TWC 324 & SC $24 \times$ Sids $7 \quad$ (W) \\
\hline
\end{tabular}

Single cross $=\mathrm{SC}$, Three way cross $=\mathrm{TWC}, \mathrm{W}=$ White and $\mathrm{Y}=$ Yellow

Randomized complete block design with four replications was used. Each plot included two ridges with $6 \mathrm{~m}$ long, spaced $0.7 \mathrm{~m}$ apart and $25 \mathrm{~cm}$ between hills with two seeds in each hill and thinned to one plant at thinning. All recommended practices were done as usual in maize fields. Data of days to $50 \%$ tasseling (DTT) and days to $50 \%$ silking (DTS) were recorded on the plot basis. At harvest, ten plants were randomely chosen to collect data on the following traits:

1. Plant height $(\mathrm{cm}) \quad(\mathrm{PH})$

2. Ear height $(\mathrm{cm}) \quad(\mathrm{EH})$

3. Number of ears plot ${ }^{-1} \quad$ (NEP)

4. Ear length $(\mathrm{cm}) \quad$ (EL)

5. Ear diameter $(\mathrm{cm}) \quad$ (ED)

6. Cub diameter $(\mathrm{cm}) \quad$ (CD)

7. Kernel depth $(\mathrm{cm}) \quad(\mathrm{KD})$

8. Number of rows ear ${ }^{-1} \quad$ (NRE)

9. Number of kernels row ${ }^{-1} \quad$ (NKR)

10. Grain yield (GY) was firstly determined according to the plot area. Then, the yield data were adjusted to $15.5 \%$ moisture content and then converted to the unit of (ton ha $\left.{ }^{-1}\right)$. 
Statistical analysis

The current work aims to explore the true relationships among the grain yield $(\mathrm{GY})$ as a dependent variable and the other eleven traits as independent variables using conventional and modified models of path analysis. The used statistical techniques were as follows:

\section{Correlation matrix}

simple correlation coefficients was computed among various characters as outlined by Snedecor \& Cochran (1989).

\section{Conventional path analysis model}

This technique was proposed by Dewey \& Lu (1959) to separate the simple correlation cofficient between the seed yield (as the resultant variable) and its components (as explontory variables) into direct (path coffecient) and indirect effects (that affect grain yield through the other variables). But, path coefficient is a standardized partial regression coefficient, therefore, orthogonality (no or weak associations among yield components) is a necessary assumption to satisfy goodness of fit for the path analysis model (Neter et al., 1996).

In fact, the independence among yield components is rarely found under the field conditions. This case is usually called a multicollinearity proplem. Gravois \& Helms (1992) mentioned that when the ordinary path analysis model is used in the presence of multicollinearity, some path coefficient may exceed one, which is considered a negative effect of multicollinearity. Neter et al., (1996) documenteds in details the adverse effects of multicollinearity on the multiple linear regression model. Also, Williams et al. (1979) stated that the negative effects of multicollinearity may be enough to reject the ordinary path analysis model. A common measure called Variance Inflation Factor (VIF) as suggested by Hair et al. (1992) was used to test the presence of multicollinearity. If the VIF value is above 10 , this indicates the presence of multicollinearity, then the model could be rejected.

\section{Modified path analysis model}

This model was proposed by Carvalho et al. (1999) to correct the negative effects of multicollinearity problem. The proposed model (sometimes called ridge path analysis model) is considered as an adjusted shape of the ordinary path analysis model. The objective model would be applied by adding a small bias constant value (k) to the diagonal elements (unity value) of the correlation matrix among yield components. The $\mathrm{k}$ value would be located in the range from zero to one. When $\mathrm{k}=0$, the modified model would be reduced to the normal model. The optimum value of $\mathrm{k}$ is determined using two methods, i.e. ridge trace exam (Hoerl \& Kennard, $1970 \mathrm{a}$ and b) and VIF values.

The ridge trace exam appeared as a two-dimensional chart showing how the path coffections vary as a function of $\mathrm{k}$ in the interval $0<\mathrm{k}<1$. The smallest value of $\mathrm{k}$ which is capable of stablizing most path coefficients (less than unity) and at the same time have low VIF values (less than 10) would be the optimum value of $k$.

Egypt. J. Agron. 34, No. 2 (2012) 
Descriptive statistics

\section{Results and Discussion}

The descriptive statistics, i.e. mean, median, standrad deviation (SD), standard error (SE) and coefficient of variation (CV) for yield and its components are shown in Table 2. Results showed that the values of SD and SE were in the allowed limit compared to the mean values of all characters. Therefore, the CV values are located at the statistically acceptable range as recommended in field experiments

TABLE 2. Descriptive statistics of grain yield and its related characters in maize.

\begin{tabular}{|c|c|c|c|c|c|c|}
\hline \multirow{2}{*}{ No. } & \multirow{2}{*}{ Traits } & \multicolumn{5}{|c|}{ Descriptive Statistics } \\
\hline & & Mean & Median & SD & SE & $\mathrm{CV}$ \\
\hline 1 & \begin{tabular}{|llll}
$\begin{array}{l}\text { Days to } \\
\text { tasseling }\end{array}$ & 50 & $\%$ \\
\end{tabular} & 60.15 & 58.88 & 2.71 & 0.43 & 4.51 \\
\hline 2 & Days to $50 \%$ silking & 61.50 & 61.53 & 2.77 & 0.44 & 4.50 \\
\hline 3 & Plant height & 255.01 & 252.28 & 19.85 & 3.14 & 7.78 \\
\hline 4 & Ear height & 144.00 & 143.07 & 6.16 & 0.97 & 4.28 \\
\hline 5 & No. of ears plot ${ }^{-1}$ & 49.25 & 49.58 & 2.55 & 0.40 & 5.17 \\
\hline 6 & Ear length & 21.18 & 20.76 & 1.65 & 0.26 & 7.78 \\
\hline 7 & Ear diameter & 5.17 & 5.20 & 0.27 & 0.04 & 5.28 \\
\hline 8 & Cub diameter & 3.13 & 3.13 & 0.08 & 0.01 & 2.47 \\
\hline 9 & Kernel depth & 1.02 & 1.02 & 0.11 & 0.02 & 11.22 \\
\hline 10 & No. of rows ear ${ }^{-1}$ & 14.01 & 14.08 & 0.34 & 0.05 & 2.43 \\
\hline 11 & No. of kernels row ${ }^{-1}$ & 43.04 & 43.06 & 3.25 & 0.52 & 7.55 \\
\hline 12 & Grain yield $\left(\right.$ ton $\mathrm{ha}^{-1}$ ) & 11.03 & 10.93 & 1.093 & 0.193 & 9.92 \\
\hline
\end{tabular}

\section{Correlation matrix}

The correlation coefficients among yield and yield components are presented in Table 3. Highly significant and posistive associations were obtained between grain yield and each of days to $50 \%$ tasseling, days to $50 \%$ silking, ear height, number of ears plot ${ }^{-1}$, ear length and number of kernels row ${ }^{-1}$. The associations between grain yield and each of ear diameter, cub diameter, kernel depth and number of rows ear $^{-1}$ were negative and highly significant. The relationships between grain yield and each one of the studied characters are graphically illustrated in Fig 1 .

Results revealed some important patterns of associations among yield components. Because of positive and highly significant correlation among them, similar trend of associations with most characters were obtained for days to $50 \%$ tasseling and days to $50 \%$ silking. Highly significant and positive correlation was found between each of the previous two traits and each of ear height $(0.754 * *$ and $0.788 * *)$, number of ears $\operatorname{plot}^{-1}(0.628 * *$ and $0.724 * *)$ and ear length $(0.882 * *$ and $0.928 * *)$ while their associations with each of ear diameter $(-0.874 * *$ and $-0.940 * *)$, cub diameter $(-0.582 * *$ and $-0.610 * *)$, kernel depth $(-850 * *$ and $-919 * *)$ and number of rows $\operatorname{ear}^{-1}(-0.567 * *$ and $-0.577 * *)$ were negative and highly significant. No significant relationships were obtained between plant height and the studied characters. 
Highly significant and negative associations were recorded between each of ear height and ear length on one side and each of ear diameter $\left(-0.705^{* *}\right.$ and $\left.-0.914^{* *}\right)$, cub diameter $\left(-0.381^{* *}\right.$ and $\left.-570^{* *}\right)$, kernel depth $\left(-0.714^{* *}\right.$ and $-0.902 * *)$ and number of rows $\operatorname{ear}^{-1}(-0.502 * *$ and $-0.654 * *)$ on the other side while their correlations with number of kernels $\operatorname{row}^{-1}\left(0.417^{* *}\right.$ and $\left.0.476^{* *}\right)$ were positive and highly significant.

TABLE 3. Correlation coefficients between all pairs of yield components in $\operatorname{maize}(\mathbf{n}=32)$.

\begin{tabular}{|c|c|c|c|c|c|c|c|c|c|c|c|c|}
\hline Traits & DT & DS & PH & EH & NEP & EL & ED & CD & KD & NRE & NKR & GY \\
\hline DTT & 1 & & & & & & & & & & & \\
\hline DTS & $0.945 * *$ & 1 & & & & & & & & & & \\
\hline PH & 0.050 & 0.038 & 1 & & & & & & & & & \\
\hline $\mathrm{EH}$ & $0.754 * *$ & $0.788 * *$ & 0.068 & 1 & & & & & & & & \\
\hline NEP & $0.628 * *$ & $0.724 * *$ & -0.011 & $0.597 * *$ & 1 & & & & & & & \\
\hline EL & $0.882 * *$ & $0.928 * *$ & 0.066 & $0.785 * *$ & $0.707 * *$ & 1 & & & & & & \\
\hline ED & $-0.874 * *$ & $=0.940$ *** & 0.047 & $-0.705^{* * *}$ & $0.661 * *$ & $0.914 * *$ & 1 & & & & & \\
\hline $\mathrm{CD}$ & $-0.582 * *$ & $=0.610^{* * *}$ & 0.015 & $-0.381 *$ & -0.235 & $-0.570 * *$ & $0.676 * *$ & 1 & & & & \\
\hline $\mathrm{KD}$ & $-0.850 * *$ & $0.919 * *$ & 0.052 & 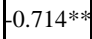 & $0.711^{* *}$ & $=0.902 * *$ & $0.969 * *$ & $0.472 * *$ & 1 & & & \\
\hline NRE & $0.567 * *$ & 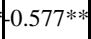 & -0.161 & 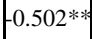 & -0.257 & $-0.654 * *$ & $0.655 * *$ & $0.546 * *$ & $0.599 * *$ & 1 & & \\
\hline NKR & 0.171 & $0.475 * *$ & 0.005 & $0.417 * *$ & $0.499 * *$ & $0.476^{* *}$ & $=0.483 * *$ & -0.264 & $-0.488 * *$ & -0.254 & 1 & \\
\hline GY & $0.778 * *$ & $0.858 * *$ & -0.011 & $0.618^{* *}$ & $0.840^{* *}$ & $0.894^{* *}$ & $=0.867^{* *}$ & $-0.458^{*}$ & $0.882 * *$ & $-0.466^{* * *}$ & $0.509^{* *}$ & 1 \\
\hline
\end{tabular}

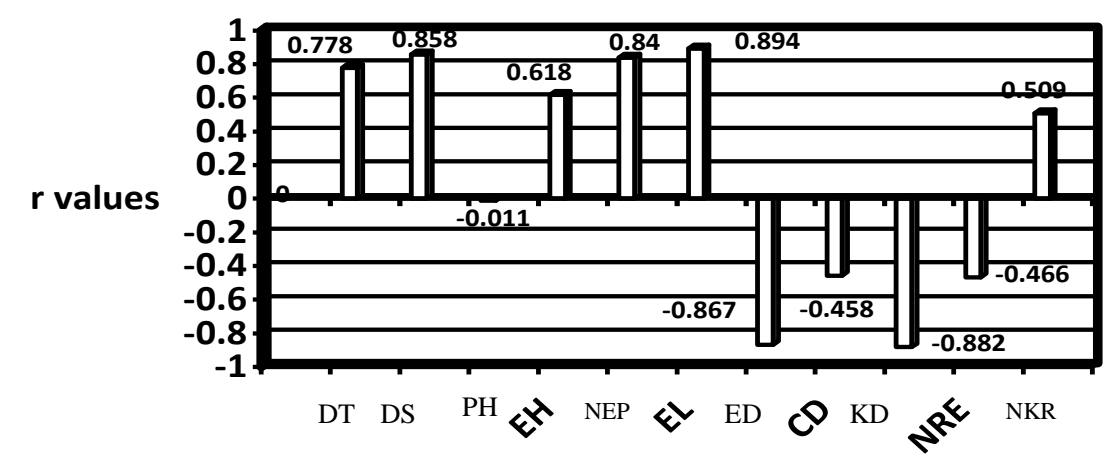

Characters

Fig. 1. Correlation coefficients between grain yield and its related characters over the two season $(n=25)$.

Egypt. J. Agron. 34, No. 2 (2012) 
In the same veiw, highly significant and positive relationships were recorded between each of cub diameter and kernel depth on one side with number of rows ear $^{-1}\left(0.546^{* *}\right.$ and $\left.0.599 * *\right)$ on the other side. These findings are in accordance with those obtained by EL-Taweel \& Barakat (2006).

\section{Path analysis}

Simple correlation coefficient measures one directional relationship between two traits neglecting the effects of other traits on the two correlated traits. Therefore, the selection decisions depending only on the correlation coefficient may not always be effective. Path analysis procedure provides a clear picture about the complicated interrelatioships among the studied traits.

The direct effects of the studied traits using the conventional and modified path analysis models as well as their corresponding VIF values are listed in Table 4 to discuss the validity and goodness of fit for the two used models.

TABLE 4. Estimates of direct effects for agronomic traits of maize according to conventional $(K=0)$ and modified path analysis models $(K=0.3)$.

\begin{tabular}{|l|c|c|c|c|c|}
\hline \multirow{2}{*}{ No. } & \multirow{2}{*}{$\begin{array}{c}\text { Yield } \\
\text { components }\end{array}$} & \multicolumn{2}{c|}{ Conventional model (k=0) } & \multicolumn{2}{c|}{ Modified model (k= 0.3) } \\
\cline { 3 - 6 } & effect & VIF & $\begin{array}{c}\text { Direct } \\
\text { effects }\end{array}$ & VIF \\
\hline 1 & DTT & -0.110 & 259.90 & 0.076 & 0.281 \\
\hline 2 & DTS & -0.083 & 286.30 & 0.085 & 0.237 \\
\hline 3 & PH & 0.057 & 1.300 & 0.018 & 0.591 \\
\hline 4 & EH & -0.219 & 3.700 & -0.078 & 0.723 \\
\hline 5 & NEP & 0.398 & 3.500 & 0.284 & 0.694 \\
\hline 6 & EL & 0.635 & 15.500 & 0.230 & 0.489 \\
\hline 7 & ED & 2.189 & 2390.70 & -0.148 & 0.216 \\
\hline 8 & CD & -0.700 & 191.70 & -0.008 & 0.636 \\
\hline 9 & KD & -2.230 & 1690.50 & -0.172 & 0.355 \\
\hline 10 & NRE & 0.118 & 2.700 & 0.026 & 0.691 \\
\hline 11 & NKR & -0.028 & 35.50 & 0.067 & 0.576 \\
\hline
\end{tabular}

Regarding the conventional form of path analysis, undesirable results were obtained as a bad consequence for the presence of multicollinearity. The irregular values of VIF (above 10) for most studied traits, i.e. days to $50 \%$ 
tasseling (259.9), days to $50 \%$ silking (286.3), ear length (15.5), ear diameter (2390.7), cub diameter (191.7) kernel depth (1690.5) and number of kernels row $^{-1}(35.5)$ are clear indicators that the assumption of independency among yield components is violated.

On the other hand, the path coefficients (direct effects) were fluctuated recording very low values (close to be zero) and other inflated values (above 1). For example, the path coefficients for ear diameter (2.189) and kernel depth (-2.23) were more than 1. Gravois \& Helms (1992) reported that if the path coefficient is above (1), it would reflect a bad effect of multicollinearity. In contrast, days to $50 \%$ silking $(-0.083)$, plant height $(0.057)$ and number of kernels row $^{-1}(-0.028)$ recorded very small values.

In addition to the previous negetive effects, path coefficient sometimes had unexpected wrong sign that did not agree with most litratures which considered the most serious effect of multicollinearity. In the present study, the direct effect of number of kernels row $^{-1}(-0.028)$ was negative and very small. This result conflicted with most references that confirmed the magnitude of number of kernels row $^{-1}$ as a main yield component of maize.

Statistically, the previous results of normal path analysis, which due to multicollinearity, are enough to reject this model and give us the justification to use an alternative model to avoid these negative effects. Kozak \& Kang (2006) pointed out that using the traditional path analysis model would become out of date compared to the modern models of path analysis (ridge path analysis and sequential path analysis).

Carvalho et al. (1999) introduced an alternative form of path analysis that could reduce the adverse effects of multicollinearity. The model adds very small positive constant value $(\mathrm{K})$ ranging from zero to unity ( 0 to 1$)$, to the diagonal elements of the simple correlation matrix, as the ridge regression analysis proposed by Hoerl \& Kennard (1970 a and b). Hence, the proposed model of path analysis is considered as a simple modification of the original model of the path analysis.

In the current study, the optimum value of the constant $(\mathrm{K})$ is detected by ridge trace exam. In this exam, the path coefficients are estimated under different values of $\mathrm{K}$. The results of ridge trace exam are graphically illlustrated in Fig. 2. The optimum $\mathrm{K}$ value is determined when the path coefficients for all traits became stable and parallel which happened at 0.3 .

More accurate parameters were obtained using the modified path analysis model (Table 4). For instance, the VIF values for eleven traits were less than 10 at $\mathrm{K}=0.3$ indicating a successful choice of $\mathrm{K}$ value at 0.3 . Also, the proposed modified model makes the path coefficient for all traits less than 1 . Moerover, the path coefficient for number of kernels row $^{-1}(0.067)$ became positive which agreed with most literatures. Accordingly, modified model (ridge path analysis )

Egypt. J. Agron. 34, No. 2 (2012) 
has more validity and considered an effective corrected tool to overcome the multicollinearity dilemma. Therefore, the remainder part of this paper would focus only on the results of the valid model (ridge path analysis ).

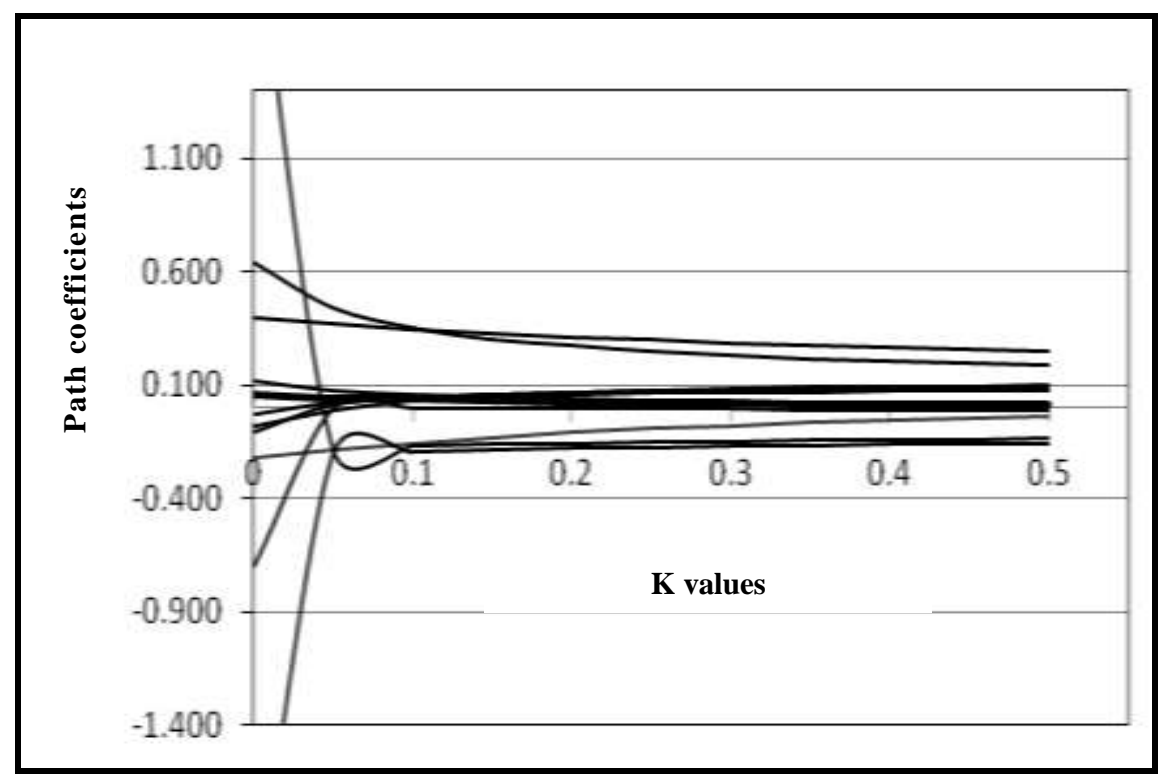

Fig. 2. Path coefficients as a function of $k$ values ranged from 0 to 0.5 .

Results in Table 4 recorded positive direct effects for all studied traits except for ear height, ear diameter, cub diameter and kernel depth which had negative direct effects. The maximum positive direct effects were obtained by number of ears $\operatorname{plot}^{-1}(0.284)$ followed by ear length $(0.230)$ indicating that the indirect selection for grain yield through the previous two traits would be effective to improve yield productivity in maize. Similar results were obtained by Carvalho et al. (2001) who found that ridge path analysis model was more valid and precise compared to the ordineary path analysis model in maize. In fact, the modified path analysis model gave somewhat a clear picture compared to the simple correlation coefficient. For example, the simple correlation coefficient between grain yield and ear height $\left(0.618^{* *}\right)$ reflects feeling that ear height had strong positive effect on grain yield while the proposed path analysis model revealed that ear height had negative and low direct effect on grain yield (-0.078). These findings were supported by Bhatt (1973) who documented that the path analysis gives a true picture about the complicated interlationships among the studied traits.

The coefficient of determination (CD) and relative importance (RI \%) for the different traits computed using the proposed model of path analysis are 
presented in Table 5.The direct effect for the eleven studied traits accounted for $21.13 \%$ of the grain yield variation. The results revealed that the greatest parts of grain yield variation were explained by the direct effects of the traits, i.e. number of ears plot $^{-1}$ (8.1\%), ear length (5.32\%), kernel depth (2.97) and ear diameter (2.22). Concerning the relative importance of the indirect effect, it appeared that the highest values were obtained for number of ears plot $^{-1}$ through its associations with each of ear length (7.147), kernnel depth (5.367) and ear diameter (4.318). Also, considerable indirect components for ear length were obtained via each of kernel depth (5.519) and ear diameter (4.832). Moderate values of joint effects ranged from 2.057 to 3.831 were recorded for $50 \%$ days to tasseling, days to $50 \%$ silking, ear height and ear diameter through the other traits.

The remaining joint effects for the different traits recorded very small or trivial values explaining $18.5 \%$ of the total variation of grain yield. The joint or indirect effects for the studied characters explained $47.35 \%$ of the total variation for grain yield. It is evident that the component of indirect effects was more important than the part of direct effects because double amount of grain yield variation was explained by the indirect effects compared to the direct effectss. Accordingly, the breeder should be more interested about the complicated associations among the characters of yield components.

Totally, the studied traits accounted for $86.98 \%$ of the grain yield variation, the residual component $(13.02 \%)$ may be due to three reasons being the random error, sampling errors and some other traits that were not included in the current study. These results are in accordance with findings observed by Ottaviano \& Camussi (1981), Ivanovic \& Rosic (1984), Arias et al. (1999), Carvalho et al. (2001) and Mohammadi et al. (2003).

Finally, it could be concluded from the current study that the two traits, i.e. number of ears plot ${ }^{-1}$ and ear length are the most reliable yield components as selection criteria in maize. These traits reflected highly significant and positive correlation with grain yield and their direct and indirect effects on yield formation process were also positive and the highest over the other yield attributes. 
TABLE 5. Coefficient of determination (CD) and relative importance (RI \%) of maize yield components using the modified path analysis model $(K=0.3)$.

\begin{tabular}{|c|c|c|c|}
\hline No. & Traits & $\begin{array}{c}\text { Coefficient of } \\
\text { determination }(\mathrm{CD})\end{array}$ & $\begin{array}{c}\text { Relative importance } \\
(\text { RI\%) }\end{array}$ \\
\hline \multicolumn{4}{|c|}{ Direct effects } \\
\hline 1 & DTT & 0.007 & 0.58 \\
\hline 2 & DTS & 0.009 & 0.74 \\
\hline 3 & $\mathrm{PH}$ & 0.0004 & 0.032 \\
\hline 4 & EH & 0.008 & 0.618 \\
\hline 5 & NEP & 0.105 & 8.121 \\
\hline 6 & EL & 0.069 & 5.318 \\
\hline 7 & ED & 0.029 & 2.22 \\
\hline 8 & $\mathrm{CD}$ & 0.0001 & 0.006 \\
\hline 9 & $\mathrm{KD}$ & 0.038 & 2.974 \\
\hline 10 & NRE & 0.0009 & 0.068 \\
\hline 11 & NKR & 0.006 & 0.450 \\
\hline \multicolumn{2}{|c|}{ Total direct effect } & 0.2724 & 21.13 \\
\hline \multicolumn{4}{|c|}{ Considerable Indirect effect } \\
\hline 1 & DTT via NEP & 0.027 & 2.097 \\
\hline 2 & DTT via EL & 0.031 & 2.383 \\
\hline 3 & DTS via NEP & 0.035 & 2.702 \\
\hline 4 & DTS via EL & 0.036 & 2.803 \\
\hline 5 & DTS via KD & 0.027 & 2.076 \\
\hline 6 & EH via NEP & -0.027 & 2.057 \\
\hline 7 & EH via EL & -0.028 & 2.189 \\
\hline 8 & NEP via EL & 0.092 & 7.147 \\
\hline 9 & NEP via ED & 0.057 & 4.318 \\
\hline 10 & NEP via KD & 0.069 & 5.376 \\
\hline 11 & EL via $\mathrm{ED}$ & 0.062 & 4.832 \\
\hline 12 & EL via $\mathrm{KD}$ & 0.071 & 5.519 \\
\hline 13 & $\mathrm{ED}$ via $\mathrm{KD}$ & 0.049 & 3.831 \\
\hline \multicolumn{2}{|c|}{$\begin{array}{l}\text { Total of considerable indirect } \\
\text { effects }\end{array}$} & 0.500 & 47.35 \\
\hline \multicolumn{2}{|c|}{ Sum of trivial indirect effects } & 0.0596 & 18.50 \\
\hline \multicolumn{2}{|c|}{ Total direct and indirect effects } & 0.832 & 86.98 \\
\hline \multicolumn{2}{|c|}{ Residuals } & 0.168 & 13.02 \\
\hline \multicolumn{2}{|c|}{ Totals } & 1 & 100 \\
\hline
\end{tabular}

\section{References}

Arias, C.A.A., Souza de, C. L. and Takeda, Jr. C. (1999) Path coefficient analysis of ear weight in different types of progeny in maize. Maydica, 44 (3), 251-262.

Bhatt, G.M. (1973) Significance of path coefficient analysis in determining the nature of character association. Euphytica, 22, 338 - 343. 
Bizeti, H.S., Carvalho, C.G., Souza, J. R. and Destro, D. (2004) Path analysis under multicollinearity in soybean. Brazilian Archives of Biology and Technology, 47(5), 669-676.

Carvalho, C. G., Borsato, R. Cruz, C. D. and Viana, J.M.S. (2001) Path analysis under multicollinearity in $\mathrm{S}_{\mathrm{o}} \times \mathrm{S}_{\mathrm{o}}$ maize hybrids. Crop Breed. and Applied Bio. 1(3), 263-270.

Carvalho, S. P., Cruz, C. D. and Carvalho, C.G.P. (1999) Estimating gain by use of a classic selection under multicollinearity in wheat (Triticum aestivum). Genetics and Molecular Biology, 22, 109-113.

Dewey, D.R. and Lu, K.H. (1959) A correlation and path coefficient analysis of components of crested wheat grass seed production. Agron. J. 51, 515-518.

EL-Taweel, A. M. S. A. and Barakat, Somia, A. (2006) Statistical studies on designed and uniformity trials to detect the interrelation among yield and its components in maize. Egypt. J. Plant Breed. 10 (2), 65-78

Gravois, K.A. and Helms, R.S. (1992) Path analysis of rice yield and yield components as affected by seeding rate. Agron. J. 84, $1-4$.

Hair, J.F., Anderson, J.R., Tatham, R.L. and Black, W.C. (1992) "Multivariate Data Analysis”. MacMillan Pub. Comp., A Division of MacMillan, Inc., USA.

Hoerl, A.E. and Kennard, B.G. (1970a) Ridge regression: applications to monorthogonal problems. Technometrics, 12, 69-82.

Hoerl, A.E. and Kennard, B.G. (1970b) Ridge regression: biased estimation for monorthogonal problems. Technometrics, 12, 55-68.

Ivanovic, R.M. and Rosic, K.R. (1984) path coefficient analysis for three stalk traits and yield in maize. Maydica, 30, 233-239.

Kang, M.S. (1994) “Applied Quantitative Genetics". M.S. Kang Publisher, Baton Rouge, LA. USA.

Kozak, M. and Kang, M.S. (2006) Note on modern path analysis in application to crop science. Communications in Biometry and Crop Science, 1, 32 -34.

Mohamed, M.K. and Sedhom, S.A. (1993) A comparison between four statistical procedures of relating yield components in a set of corn varieties. Annals Agric. Sci., Moshtohor, 31(4), 1856-1865.

Mohammadi, S. A., Prasanna, B. M. and Singh, N. N. (2003) Sequential path model for determining interrelationships among grain yield and related characters in maize. Crop Sci. 43, 1690-1697.

Neter, J., Kutner, M.H. Wasserman, W. and Nachtsheim, C.J. (1996) “Applied Linear Statistical Models". $4^{\text {th }}$ ed., McGraw-Hill/Irwin, Boston, Chicago. 
Ottaviano, E. and Camussi, A. (1981) Phenotypic and gentic relationships between yield comonents in maize. Euphytica, 30, 601-609.

Rafiq, C.M., Rafique, M., Hussain, A. and Altaf, M. (2010) Studies on heritability, correlation and path analysis in maize (Zea mays L.). J. Agric. Res. 48 (1), 35 - 38.

Saidaiah, P., Satyanarayana, E. and Kumar, S.S. (2008) Association and path coefficient analysis in maize (Zea mays L.). Agric. Sci. Digest, 28 (2), 79 - 83.

Snedecor, G.W. and Cochran, W.G. (1989) "Statistical Methods". $8^{\text {th }}$ ed., Iowa State University Press, Ames, Iowa, USA

Wannows, A.A., Azzam, H.K. and Al-Ahmad, S.A. (2010) Genetic variances, heritability, correlation and path coefficient analysis in yellow maize crosses (Zea mays L.). Agric. Biol. J. N. Am. 1(4), 630 - 637.

Williams, W.A., Qualset, C.O. and Geng, S. (1979) Ridge regression for extracting soybean yield factors. Crop Sci., 19, $869-873$.

(Received 16/10/2012; accepted 25/ 12 /2012
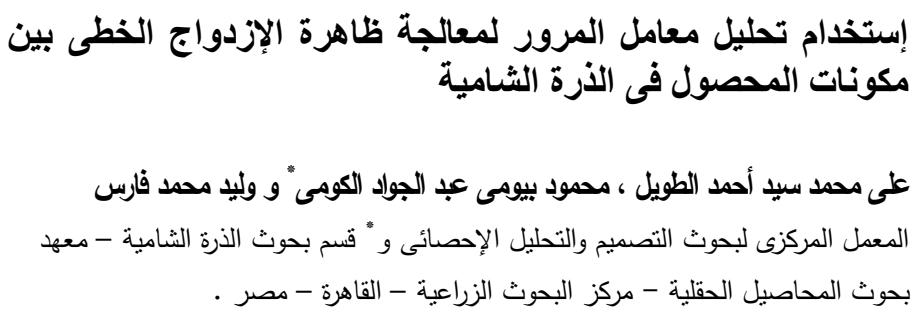

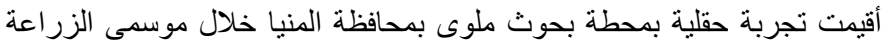

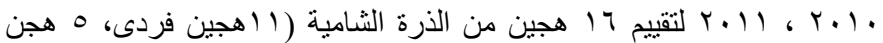

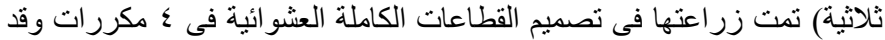

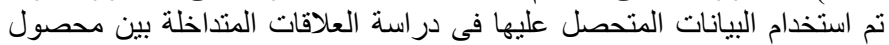

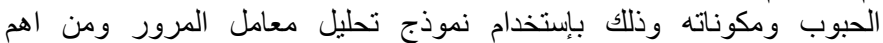

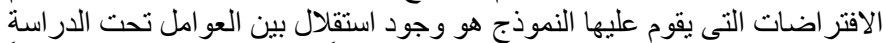

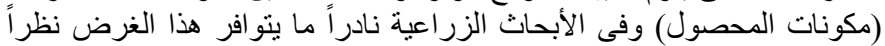

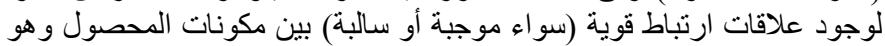

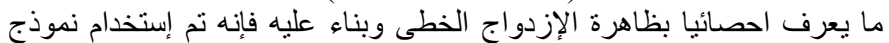

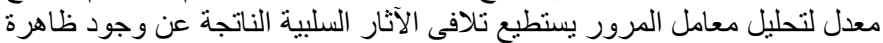

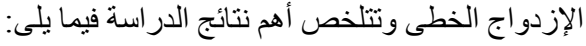

أشارت الدر اسة إلى وجود علاقة إرتباط موجب و عالى المعنوية بين محصول

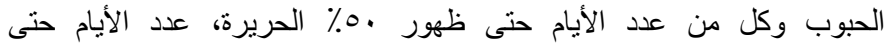

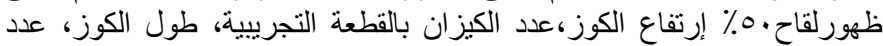

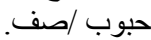




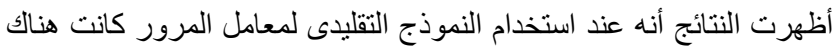

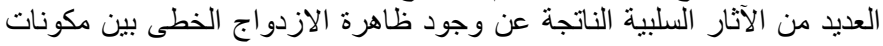

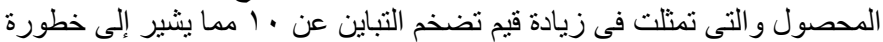

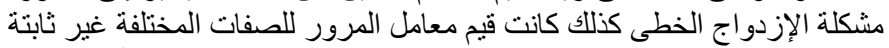

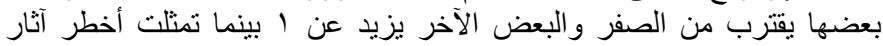

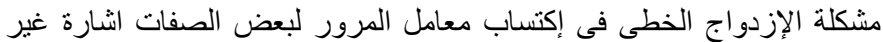

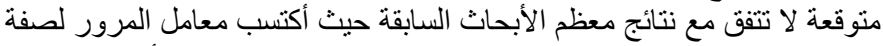

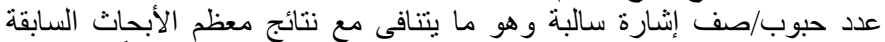
وبناء على ما سبق فإن هذه الآثار السلبية تكفى لرفض الرف النموذج إحصائياً.

أدى إستخدام النموذج المعدل من تحليل معامل المرور إلى تجنب معظم

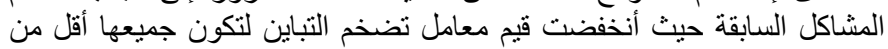

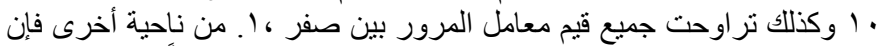

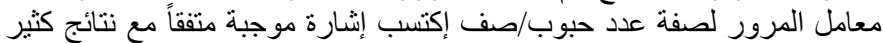
من الابحاث السابقة.

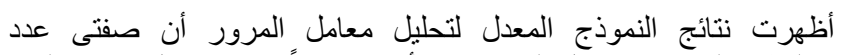

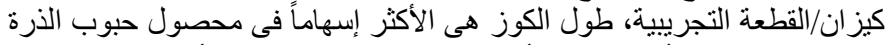

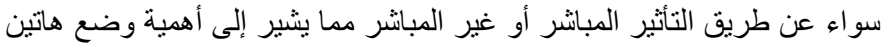

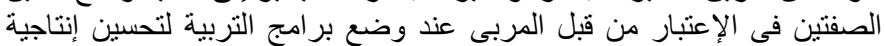
محصول الذرة الثنامية. 